ks. Tomasz Bać, Przestrzeń liturgiczna w konstantyńskiej bazylice Bożego Grobu i Zmartwychwstania Pańskiego w Jerozolimie, w: Przestrzeń liturgiczna, red. Adelajda Sielepin CHR, Jarosław Superson SAC, Kraków 2019, s. 55-74.

DOI: http://dx.doi.org/10.15633/9788374387828.04

ks. Tomasz Bać

Rzeszów

\title{
Przestrzeń liturgiczna w konstantyńskiej bazylice Bożego Grobu i Zmartwychwstania Pańskiego w Jerozolimie
}

Cechą charakterystyczną Kościoła w Jerozolimie jest jego ścisły związek z miejscami, w których dokonały się wydarzenia związane z życiem i paschalnym misterium Jezusa Chrystusa. Szczególnie wyraźnie zależność tę można dostrzec $\mathrm{w}$ liturgii, która już w pierwszych jerozolimskich tekstach źródłowych określana bywała często mianem apta loco, czyli celebrowana w taki sposób, aby jej poszczególne elementy, takie jak oracje, psalmy czy gesty były dostosowane do konkretnego miejsca, w którym modlił się Kościół. Na planie Jerozolimy doby późnego antyku i epoki bizantyjskiej centralny punkt wyznaczają imponujące budowle sakralne wzniesione z polecenia cesarza Konstantyna Wielkiego, mające być upamiętnieniem (gr. martyrion) męki i śmierci Chrystusa. To wokół nich przez prawie siedem wieków koncentrowało się życie liturgiczne Świętego Miasta. Chociaż po splendorze tych budowli dzisiaj nie zostało już wiele, to jednak wiele obrzędów w nich celebrowanych pozostawiło trwały ślad w liturgii chrześcijańskiego Wschodu i Zachodu. Warto zatem, na podstawie dostępnych źródeł liturgicznych Jerozolimy pochodzących z pierwszego tysiąclecia, przyjrzeć się przestrzeni liturgicznej i jej organizacji w budowlach wzniesionych przez Konstantyna Wielkiego na Golgocie. W tym czasie nie można jeszcze mówić o jednej Bazylice Bożego Grobu lub, jak wolą mówić chrześcijanie wschodni, bazylice Zmartwychwstania Pańskiego, ale o kompleksie sakralnym złożonym z kilku budowli, mającym upamiętnić śmierć i zmartwychwstanie Chrystusa. 


\section{I. ŹRÓDŁA LITURGII JEROZOLIMSKIEJ POMIĘDZY IV A XI WIEKIEM}

Z okresu, w którym w kompleksie budynków sakralnych wzniesionych przez cesarza Konstantyna Wielkiego w miejscu śmierci i zmartwychwstania Chrystusa odbywały się rzeczywiście celebracje Kościoła jerozolimskiego, czyli od pierwszej połowy IV wieku aż do roku I009, zachowało się kilka ważnych dla historii dokumentów o charakterze liturgicznym. Rzucają one światło na strukturę celebracji oraz na ich przestrzenną organizację. Dokumenty te obejmują zarówno księgi liturgiczne, jak i opisy celebracji, a także notatki z podróży do Ziemi Świętej oraz katechezy i homilie wygłaszane w tych właśnie miejscach. Są one również świadectwem rozwoju liturgii jerozolimskiej, która w ciągu wieków zmieniała się przybierając nowe formy ${ }^{\mathrm{I}}$.

Pierwszym i fundamentalnym dla badaczy liturgii jerozolimskiej źródłem, któremu w niniejszej pracy zostanie poświęcone najwięcej miejsca, jest Itinerarium [dalej: IE], czyli notatki z pielgrzymki do Ziemi Świętej i na Bliski Wschód, jaką w przedostatniej dekadzie IV wieku odbyła pątniczka o imieniu Egeria pochodząca z Galii lub Hiszpanii². W czasie pielgrzymki Egeria odwiedziła oczywiście Jerozolimę, pozostawiając w swym dzienniku szczegółowy opis obrzędów, w których brała udział osobiście oraz zamieszczając informacje, które jej przekazywano. Bardzo wiele uwagi poświęciła miejscom celebracji, a także osobom, które brały w nich udział, opisując zarówno liturgie o charakterze katedralnym, jak i te o charakterze monastycznym oraz obrzędy związane z katechumenatem i przygotowaniem do sakramentów inicjacji chrześcijańskiej. W swoim tekście zawarła wiele wyjaśnień, osobistych komentarzy oraz porównań do znanej jej liturgii zachodniej. Wszystko to sprawia, że opis Egerii jest bezcenny dla historii liturgii jerozolimskiej.

I Por. S. Janeras, La Settimana Santa nell'antica liturgia di Gerusalemme, w: Hebdomadae Sanctae celebratio. Conspectus historicus comparativus, cura et studio A. G. Kollamparampil, Roma 1997, s. I9-20.

Itinerarium Egeriae [dalej: IE], a cura di A. Franceschini, R. Weber, w: Itineraria et alia geographica, Turnhout 1958, s. 29-I03 (Corpus Christianorum. Series Latina 175). Opracowanie polskie: Egeria, Pielgrzymka do miejsc świętych, w: Do Ziemi Świętej. Najstarsze opisy pielgrzymek do Ziemi Świętej IV-VIII w., red. P. Iwaszkiewicz, Kraków 20ı, s. II8-I99. Według historyków Egeria przebywała w Jerozolimie najprawdopodobniej w roku 383. Por. S. N. Klimas, Autentyczność Bożego Grobu w Jerozolimie. Badania historiograficzne, archeologiczno-architektoniczne i udokumentowane w zabytkach (I-Xw.), Kalwaria Zebrzydowska 20I7, s. $377-38$ I. 
Kolejnym źródłem opisującym przestrzeń liturgiczną w kompleksie budowli sakralnych wzniesionych przez Konstantyna Wielkiego w miejscu śmierci i zmartwychwstania Jezusa są homilie chrzcielne i mistagogiczne biskupa Jerozolimy Cyryla, pochodzące również z końcowych dekad IV wieku. W homiliach i katechezach wygłaszanych do katechumenów i neofitów biskup odnosił się także do miejsc, w których dokonywały się poszczególne obrzędy, nadając im najbardziej oryginalną interpretację teologiczną i liturgiczną. $\mathrm{Z}$ początku $\mathrm{V}$ wieku pochodzą źródła tradycji ormiańskiej, wśród których na pierwsze miejsce zdecydowanie wysuwa się tzw. Lekcjonarz ormiański, opublikowany w I97I roku przez Athanasego Renoux³ ${ }^{3}$ Kolejne źródła jerozolimskie opisujące następny etap rozwoju liturgii Świętego Miasta (w wiekach pomiędzy V a VIII) to dokumenty tradycji gruzińskiej, wśród których zdecydowanie na czoło wysuwa się tzw. Wielki lekcjonarz Kościoła jerozolimskiego opublikowany w latach I959-I960 przez Michela Tarchnischvilego4. Wreszcie ostatnim dokumentem źródłowym opisującym celebracje liturgiczne Jerozolimy na przełomie pierwszego i drugiego tysiąclecia jest tzw. Typikon kościoła Anastasis. Sam tekst księgi zawarty jest w dopiero XII wiecznym manuskrypcie znanym jako Hagios Stauros 43, jednak historycy nie mają wątpliwości, że opisana tam liturgia dotyczy celebracji sprzed zburzenia bazyliki Konstantyna i rotundy Zmartwychwstania Pańskiego w Ioog rokus. Wiele fragmentów Typikonu oraz bardzo szczegółowy opis zamieszczonych w nim celebracji zawarł Jean-Baptiste Thibout w swojej pracy opublikowanej w roku $1926^{6}$.

3 Le codex arménien Jérusalem I2I, t. 2: Édition comparée du texte et de deux autres manuscrits. Introduction, textes, traduction et notes par A. Renoux, Turnhout I97I. Szczególną wagę mają dwa spośród trzech opublikowanych manuskryptów, gdyż według badaczy są one świadectwem dwóch różnych etapów rozwoju liturgii jerozolimskiej. Stadium wcześniejsze reprezentuje manuskrypt Jerusalem Armenian I2I powstały między rokiem 4I7 a 439, manuskrypt Paris B. N. arm. 44 jest natomiast późniejszy, gdyż powstał w latach 439-442. Por. J. F. Baldovin, The Urban Character of Christian Worship. The Origins, Development, and Meaning of Stational Liturgy, Roma 1987, s. 65.

4 Le grand lectionnaire de l'Église de Jérusalem (Ve-VIII $)$, t. I-2, éd. M. Tarchnischvili, Louvain 1959-1960.

5 Por. R. Salvarani, Il Santo Sepolcro di Gerusalemme. Riti, test, e racconti tra Costantino e l'età delle crociate, Città del Vaticano 20I2, s. I66.

$6 \quad$ J.-B. Thibaut, Ordre des Offices de la Semaine Sainte à Jérusalem du IV au $X^{\mathrm{e}}$ siècle. Études de liturgie et de la topographie palestiniennes, Paris 1926. Oryginalny tytuł księgi brzmi: Porządek świętych obrzędów Wielkiego Tygodnia Męki naszego Pana Jezusa Chrystusa 
Kolejne źródła liturgiczne, już dużo liczniejsze i bardziej szczegółowe, pochodzą dopiero z epoki krzyżowców, czyli z XII wieku. Bazylika wzniesiona przez cesarza Konstantyna Wielkiego w IV wieku została jednak zburzona u początku XI wieku i wraz z nią zniknęła przestrzeń liturgiczna, w której przez bez mała siedem wieków chrześcijanie Jerozolimy celebrowali liturgię i modlili się, a przez długi czas także bronili jej przed najazdami nieprzyjaciół.

\section{ChrześciJańSKa Jerozolima I JEJ MIEJSCA KULtU W PIERWSZYM TYSIĄCLECIU}

Pochodzące z pierwszego tysiąclecia chrześcijaństwa pisane źródła liturgiczne dotyczące Jerozolimy, o których była mowa wyżej, bardzo jasno i wyraźnie odwołują się do miejsc, w których sprawowano poszczególne obrzędy i ryty. Właściwa ich interpretacja wymaga jednak zrozumienia uwarunkowań topograficznych, przestrzennych i architektonicznych, charakterystycznych dla Świętego Miasta.

Historia chrześcijańskiej Jerozolimy rozpoczęła się właściwie dopiero u początku lat 20. IV wieku, kiedy to cesarz Konstantyn Wielki podjął decyzję, aby w miejscach związanych z misterium paschalnym Chrystusa wzniesiono kościoły, mające upamiętnić wydarzenia, które tam się dokonały. Od tego czasu Jerozolima stała się miastem całkowicie chrześcijańskim, a liturgia celebrowana w jej kościołach była wyznacznikiem życia całego miasta. Oczywiście, chrześcijanie mieszkali w Jerozolimie od samego początku, mimo prześladowań jakie bardzo szybko ich dosięgły (por. Dz 8, I-3). Nawet po zniszczeniu miasta przez wojska rzymskie w 70 roku i wypędzeniu z niego Żydów mała grupa uczniów Chrystusa pozostała w Jerozolimie, i to właśnie dzięki nim ocalała pamięć o miejscach, w których dokonały się najważniejsze wydarzenia z życia Jezusa Chrystusa. Przyjmuje się, że siedzibą jerozolimskich chrześcijan był Syjon, gdzie od początku i nieprzerwanie celebrowano liturgię?.

celebrowanych w bazylice Anastasis, wedtug starożytnej praktyki Kościoła jerozolimskiego. Por. B. J. F. Baldovin, The Urban Character..., dz. cyt., s. 80, przyp. 174.

7 Por. H. Seweryniak, Geografia wiary, Warszawa 20IO, S. 22I-23I. 
Ważną datą w historii Jerozolimy był rok I35, kiedy to miasto zostało doszczętnie zniszczone przez wojska cesarza Hadriana, a później całkowicie przebudowane w stylu rzymskim. Otrzymało ono nazwę Aelia Capitolina, a wszystkie miejsca, w których rozgrywały się wydarzenia związane z życiem i Paschą Jezusa Chrystusa, zamieniono na ośrodki kultów pogańskich i chrześcijanie nie mieli do nich wstępu. W miejscu śmierci i zmartwychwstania Chrystusa powstał wówczas Kapitol. Dwa główne źródła chrześcijańskie opisujące zniszczenie Golgoty w II wieku to List 58 Hieronima do prezbitera Paulina oraz De Vita Constantini Euzebiusza z Cezarei, obydwa niewiele późniejsze niż prace związane z powstaniem budowli cesarza Konstantyna ${ }^{8}$. Hieronim pisze, że w celem wzniesienia w miejscu śmierci i zmartwychwstania Chrystusa świątyni poświęconej Zeusowi oraz figury Afrodyty było zniszczenie miejsc kultu chrześcijan:

Od czasów Hadriana aż do Konstantyna, przez lat około sto osiemdziesiąt, czczony był przez pogan w miejscu zmartwychwstania posąg Jowisza, a na skale ukrzyżowania marmurowa statua Wenery, bo sprawcy prześladowania uważali, że pozbawią nas wiary w Zmartwychwstanie i w Krzyż, jeśli miejsca święte bałwanami splugawią̧.

Euzebiusz z Cezarei natomiast, stosując zasady retoryki, bardzo szczegółowo oddaje wysiłek Rzymian włożony w zniszczenie Golgoty, która, dla młodego wciąż Kościoła, była już miejscem świętym:

Tę Grotę Zbawienia pewni ludzie bezbożni i niegodziwi zamierzali usunąć z oczu ludzi, w głupich rachubach spodziewając się, że w ten sposób będą mogli ukryć prawdę. Podjęli przeto wielki trud, z odległości przynosząc ziemię, i przykryli całe miejsce, następnie, gdy wznieśli się na pewną wysokość, zasypali je kamieniami i tak ukryli świętą grotę pod ciężkim ziemnym nasypem. Wówczas, aby niczego nie brakowało do realizacji ich projektu, przygotowali na tym fundamencie prawdziwie straszny grób dusz, budując mroczną świątynię martwych bożków dla nieczystego demona o imieniu Afrodyta i składali tam ohydne ofiary na skalanych i przeklętych ołtarzach.

8 Por. R. Salvarani, Costantino e la nascita dei santuari Cristiani dei luoghi santi, „Rivista Liturgica" IOO (20I3), s. 3II.

9 Hieronim ze Strydonu, List 58 do [prezbitera] Paulina, 4, w: Hieronim ze Strydonu, Listy II (5I-79), red. M. Ożóg, H. Pietras, Kraków 20I0, s. 7I(7I*). 
Uważali, że ich dzieło nie osiągnie inaczej pełnej doskonałości, jak tylko przez zupełne ukrycie Groty Zbawienia pod tymi przeklętymi nieczystościami ${ }^{10}$.

Należy zauważyć, że już sam fakt dokładnego zniszczenia Golgoty i wybudowania nad nią miejsc kultu rzymskich bóstw sugeruje, iż musiało to być miejsce odwiedzane przez chrześcijan, o dużym znaczeniu dla miejscowej ludności. Inaczej nie byłoby potrzeby wkładania aż tak wielkiego wysiłku w jej zniszczenie, zasypanie i umieszczenie dokładnie na jej miejscu świątyń pogańskich. Taki stan utrzymywał się w Jerozolimie prawie dwieście lat, do początku IV stulecia.

Ogromną zmianę w życiu Jerozolimy i chrześcijan tam żyjących przyniosła dopiero pierwsza połowa IV wieku. W tym czasie, na polecenie cesarza Konstantyna Wielkiego w Jerozolimie powstało kilka ważnych kościołów chrześcijańskich, w których zaczęto sprawować liturgię z całym jej bogactwem ${ }^{\text {II }}$. Kościoły Jerozolimy epoki Konstantyna to przede wszystkim monumentalny kompleks sakralny wybudowany na Golgocie. I znowu należy oddać głos Euzebiuszowi, który w następujący sposób przedstawił rolę cesarza w budowie na miejscu Grobu Chrystusa odpowiedniego dla tego miejsca kościoła:

[Miły Bogu cesarz] uznał, że jego obowiązkiem jest uczynić dla wszystkich obiektem znanym i godnym uwielbienia błogosławione miejsce Zmartwychwstania Pańskiego w Jerozolimie. Niezwłocznie wydał polecenie, aby wzniesiono tam dom modlitwy i uczynił to kierowany nie czysto naturalnym impulsem swoich własnych myśli, ale poruszony w duchu przez samego Zbawiciela ${ }^{12}$.

Następnie, paralelnie do opisu zniszczenia tego miejsca za czasów Hadriana, Euzebiusz przedstawił historię odnalezienia Golgoty i przywrócenia tego miejsca chrześcijanom, a także opis powstających tam budowli ${ }^{13}$. Kompleks sakralny wzniesiony przez cesarza Konstantyna na miejscu śmierci i zmartwychwstania Chrystusa składał się z trzech budowli, wzniesionych na osi wschód-zachód, które stanowiły jedną całość, chociaż tworzyły trzy oddzielne przestrzenie przystosowane do celebracji liturgii. W skład kom-

\footnotetext{
Io Euzebiusz z Cezarei, Życie Konstantyna, red. T. Wnętrzak, Kraków 2007, III, 26, s. I82-I83.

II Chrześcijańskie miejsca kultu w Jerozolimie wybudowane z polecenia Konstantyna wymienia i szczegółowo opisuje Euzebiusz z Cezarei. Por. Euzebiusz z Cezarei, Życie Konstantyna, dz. cyt., III, 25-4I, s. I82-I89.

I2 Euzebiusz z Cezarei, Życie Konstantyna, dz. cyt., II, 25, s. I82.

I3 Por. Euzebiusz z Cezarei, Życie Konstantyna, dz. cyt., III, 28-40, s. I84-I89.
} 
pleksu wchodziły w kolejności, poczynając od strony wschodniej do zachodniej: Martyrium, czyli pięcionawowa bazylika, której fasada umieszczona była przy jerozolimskim cardo maximus, od strony zachodniej zamknięta absydą, obszerny dziedziniec z trzech stron otoczony portykami, mieszczący w swojej południowo-wschodniej części skałę Golgoty oraz kaplica Anastasis, kryjąca rotundę, w centrum której znajdowała się martyrii spelunca, czyli edykuł Bożego Grobu. Prace trwały od 325 roku i trwały przynajmniej dziesięć lat, gdyż w roku 335, odbyło się uroczyste poświęcenie wzniesionego kościoła ${ }^{14}$.

Największa świetność budowli konstantyńskich to wieki IV, V i VI, kiedy to Jerozolima była miastem rzeczywiście chrześcijańskim. Wtedy to cała wspólnota Kościoła jerozolimskiego, na czele z biskupem i w otoczeniu duchowieństwa, mnichów i mniszek, mieszkańców miasta oraz licznych zwykle pielgrzymów celebrowała liturgię w rytmie roku liturgicznego oraz w miejscach upamiętniających wydarzenia z życia Chrystusa ${ }^{15}$. Z tego czasu pochodzi świadectwo Egerii, Lekcjonarz ormiański oraz część źródeł tradycji gruzińskiej.

Na początku VII wieku sakralny kompleks na Golgocie wzniesiony przez cesarza Konstantyna został po raz pierwszy bardzo poważnie zniszczony. Stało się to w roku 6I4, kiedy to Jerozolimę zdobyły wojska perskie pod dowództwem Chosroesa II. Persowie zabrali wówczas najcenniejszą relikwię dla chrześcijan Świętego Miasta, czyli relikwię Prawdziwego Krzyża, strzeżoną w bazylice konstantyńskiej. Bardzo szybko jednak, bo w zaled-

${ }^{14}$ Por. R. Salvarani, Il Santo Sepolcro..., dz. cyt. S. 5I. Wśród historyków kwestia dokładnej datacji budowy bazyliki konstantyńskiej jest ciągle obiektem badań i dyskusji. Data poświęcenia kościoła nie musiała bowiem łączyć się z datą zakończenia budowy.

is Za panowania cesarza Konstantyna Wielkiego w Jerozolimie wzniesiono także szereg innych kościołów, w miejscach, w których dokonały się poszczególne wydarzenia i etapy Paschy Chrystusa. Spośród nich należy wymienić przede wszystkim kościół na Syjonie, który już w IV wieku był identyfikowany z miejscem zesłania Ducha Świętego i spotkaniami Zmartwychwstałego z uczniami oraz cztery miejsca kultu na Górze Oliwnej, z których najważniejszym bez wątpienia była trójnawowa bazylika Eleona upamiętniająca nauczanie Chrystusa oraz Imbomon, czyli pierwsza budowla sakralna wzniesiona w miejscu wniebowstąpienia, chociaż nie jest pewne czy w IV wieku istniał tam już właściwy kościół. W epoce bizantyjskiej w Jerozolimie wybudowano kolejne miejsca kultu, z których najbardziej okazała jest bazylika poświęcona Najświętszej Maryi Pannie, zwana Nową - Nea, powstała za czasów cesarza Justyniana. Została jednak zburzona w czasie najazdu Persów w 6I4 roku i nigdy jej nie odbudowano. Szerzej zob. A. Marchadour, D. Neuhaus, La terra, la Bibbia e la storia. „, Verso il paese che io ti indicherò", Milano 2007, s. II8-II9. 
wie kilkanaście lat udało się odbudować zniszczoną świątynię, do czego przyczyniła się bardzo dynamiczna działalność Modesta, igumena klasztoru św. Teodozjusza w Deir Dosi niedaleko Betlejem, który został później patriarchą Jerozolimy. Gdy w 629 roku cesarz Herakliusz odbił z rąk Persów relikwie Krzyża Świętego, wydawało się, że życie liturgiczne Świętego Miasta może nadal być czytelnym znakiem jego chrześcijańskiego charakteru $^{16}$. To z tego czasu pochodzi świadectwo większości liturgicznych źródeł tradycji gruzińskiej.

Niestety, już w 637 roku Jerozolima została zdobyta przez umajjadzkiego kalifa Omara i od tej pory, na kolejnych kilkanaście wieków, weszła we władanie muzułmańskie. Zakończyła się wówczas epoka bizantyjska, czyli chrześcijańska w historii miasta. Wprawdzie liturgie w bazylice Bożego Grobu mogły być nadal sprawowane, ale nowi władcy wprowadzali szereg utrudnień dla chrześcijan i pielgrzymów. Nie pozwalano także na remonty i naprawy, stąd budynki istniejące od wieków były w coraz gorszym stanie. Szczególnie ważnym i brzemiennym w skutki momentem stał się rok I009, kiedy to niezrównoważony psychicznie fatymidzki kalif al-Hakim nakazał zrównanie z ziemią najważniejszych miejsc chrześcijaństwa w Jerozolimie. Jak mówią świadectwa, cegła po cegle niszczono budowle wzniesione przez Konstantyna, zaprzestając dopiero wówczas, gdy nie było już czego rozbierać. Wtedy to zupełnie zniszczono bazylikę Martyrium oraz kaplicę Anastasis, a w niej edykuł Grobu Chrystusa ${ }^{17}$.

Wprawdzie Anastasis oraz przylegające do niej budynki odbudowano już w I048 roku, na polecenie i z pomocą cesarza Konstantyna Monomacha, lecz w zupełnie innym kształcie architektonicznym. Bazylika Martyrium oraz dziedziniec-atrium poświęcone Golgocie zniknęły wówczas bezpowrotnie. W pierwszej połowie XII wieku krzyżowcy rozbudowali odnowioną świątynię i dostosowali do nowych warunków. Wtedy też bazylika przyjęła mniej więcej dzisiejszy kształt, ze zupełnie zmienioną koncepcją przestrzeni liturgicznej.

\footnotetext{
I6 Por. R. Salvarani, Il Santo Sepolcro..., dz. cyt., s. II9-I2O.

${ }_{17}$ Por. D. Galadza, La tradizione liturgica di Gerusalemme e la distruzione dei luoghi santi, „Rivista Liturgica” I0о (20I3), s. 404; szerzej zob. M. Canard, La destruction de l'eglise de la Resurrection par le calife Hakim et l'histoire de la descente du feu sacré, „Byzantion” 35 (I965), s. I6-43.
} 


\section{STRUKTURA PRZESTRZeNi LitURgiCZNEJ W KOMPLEKSIE MARTYRIUM - CRUX - ANASTASIS}

Jak zostało to już zauważone wyżej, kompleks budowli sakralnych wzniesiony przez Konstantyna Wielkiego w odnalezionym i zidentyfikowanym miejscu śmierci i zmartwychwstania Jezusa składał się z trzech budowli, zwanych tradycyjnie Martyrium, Crux lub Golgota oraz Anastasis. Każdy z nich był oddzielną przestrzenią, w której sprawowano liturgię, a wszystkie razem tworzyły pewną jedność i całość, gdyż struktura wielu celebracji przewidywała celebracje odbywające się we wszystkich trzech miejscach.

\section{I. Martyrium}

Pierwsza z trzech budowli Konstantyna na Golgocie to wielka bazylika zwana Martyrium. Egeria w następujących słowach wyjaśnia znaczenie tej nazwy, odwołując się do misterium, które w tym miejscu się dokonało: ,propterea autem Martyrum appellatur, quia in Golghota est, id est post Crucem, ubi Dominus passus est, et ideo Martyrio"I8. Sama Egeria, wspominając bazylikę, używała często określenia ecclesia maior, które służyło do podkreślenia znaczenia, piękna i bogactwa tej świątyni ${ }^{19}$. Słowa Cyryla Jerozolimskiego świadczą natomiast, że wcześniej terminem Martyrium określano zarówno bazylikę Konstantyna, jak i rotundę Anastasis jako miejsca świadectwa (gr. martyrion), jakie Chrystus złożył poprzez swoją śmierć i zmartwychwstanie ${ }^{20}$. Można jednak przyjąć, że określenie Martyrium już u końca IV wieku odnosiło się właściwie wyłącznie do bazyliki.

Od strony wschodniej otwierała się ona fasadą, która poprzez schody łączyła się z jerozolimskim cardo maximus przecinającym miasto z północy na południe. Przez troje wielkich drzwi fasady pielgrzymi wchodzili najpierw do obszernego atrium otoczonego portykami, które z kolei prowadziło ku drzwiom wejściowym samej bazyliki. Była ona największym w Jerozolimie kościołem o wymiarach 45 na 26 metrów, a jej wnętrze podzielone

\footnotetext{
I8 IE 30, I.

19 Por. E. Bermejo Cabrera, La proclamación de la Escritura en la liturgia de Jerusalén. Estudio terminologico del ,Itinerarium Egeriae”, Jerusalem I993, s. 32I-322.

20 Por. E. Bermejo Cabrera, La proclamación de la Escritura ..., dz. cyt., s. 33I; Katecheza I4, 6, w: Cyryl Jerozolimski, Katechezy przedchrzcielne i mistagogiczne, red. W. Kania, J. Bojarski, M. Bogucki, Kraków 2000, s. 2I5.
} 
zostało na pięć naw oddzielonych rzędami kolumn ${ }^{21}$. Zdobienia i wyposażenie Martyrium były godne bazyliki cesarskiej i ukazywały jej znaczenie dla chrześcijaństwa. Źródła podkreślają w niej bogactwo marmurów, szlachetnego drewna, złota, mozaik i kosztownych zdobień ${ }^{22}$. Pod posadzką bazyliki znajdowała się grota Znalezienia Krzyża Świętego, do której można było zejść schodami umieszczonymi w nawie centralnej.

W Martyrium gromadziła się zwykle wspólnota chrześcijan Jerozolimy, aby celebrować liturgie związane z miejscem śmierci i zmartwychwstania Jezusa oraz z układem roku liturgicznego ${ }^{23}$. Pierwszą przestrzeń liturgiczną tworzyło już samo wnętrze kościoła, czyli jego nawa. Według świadectwa Egerii to właśnie in medio ecclesiae maioris odbywały się niektóre ryty katechumenatu, takie jak skrutynia i katechezy głoszone do competentes każdego dnia Wielkiego Postu. $Z$ tej okazji przestrzeń liturgiczną tworzono przez wniesienie katedry biskupa i krzeseł dla prezbiterów, a wszyscy pozostali uczestnicy siadali lub stali wokół:

...zaraz potem ustawia się tron biskupa w większym kościele, w Martyrium. Wszyscy, którzy mają być ochrzczeni, siadają wokół - tak mężczyźni, jak i kobiety - zaś ich ojcowie i matki stoją. Także ci z ludku, którzy chcą się przysłuchiwać, wchodzą i siadają - jednak tylko wierni² ${ }^{24}$

Od strony zachodniej Martyrium znajdowała się absyda z dwunastoma zdobionymi srebrem kolumnami, dar samego cesarza ${ }^{25}$. W centrum absydy umieszczony był ołtarz, a na jej szczycie katedra biskupa otoczona miejscami przeznaczonymi dla prezbiterów. Katedra była przenośna. Normalnie znajdowała się w absydzie i w tym miejscu na początku Wielkiego Tygodnia odbywały się obrzędy redditio symboli:

Gdy minie owych siedem tygodni i nadejdzie tydzień paschalny, który zwą tu Wielkim Tygodniem, biskup udaje się rano do większego kościoła, do Martyrium. W głębi absydy, za ołtarzem ustawia się tron dla biskupa i podchodzą

\footnotetext{
${ }_{21}$ Por. R. Salvarani, Il Santo Sepolcro..., dz. cyt., s. 52.

22 Por. E. Bermejo Cabrera, La proclamación de la Escritura..., dz. cyt., s. 332.

23 Por. C. García del Valle, Jerusalén, la liturgia de la Iglesia madre, Barcelona 200I, s. 38.

24 IE 46, I.

25 Por. C. García del Valle, Jerusalén..., dz. cyt., s. 38.
} 
tam jeden za drugim - mężczyźni ze swoimi ojcami, a niewiasty ze swoimi matkami - i oddają Symbol biskupowi ${ }^{26}$.

O ołtarzu Martyrium Egeria wspomina tylko jeden raz, właśnie w kontekście katechumenatu. Najprawdopodobniej już w jej czasach ołtarz wykonany był ze srebra ${ }^{27}$. To na nim celebrowano Eucharystię, w której w niedziele i w najważniejsze momenty roku liturgicznego uczestniczyła cała chrześcijańska wspólnota Jerozolimy.

\subsection{Crux - Golgota}

Po obu stronach absydy Martyrium znajdowały się drzwi prowadzące ku obszernemu dziedzińcowi, otoczonemu z trzech stron portykami. To drugie miejsce wyznaczające przestrzeń liturgiczną kompleksu sakralnego wzniesionego przez Konstantyna Wielkiego i upamiętniającego śmierć i zmartwychwstanie Jezusa. Dziedziniec ten w źródłach najczęściej określany jest jako Crux lub Golgota, gdyż w jego południowo-wschodniej części znajdowała się skała Golgoty. Architekci Konstantyna zdecydowali się pozostawić ją odkrytą. Skała miała wysokość około pięciu metrów, a na jej szczycie umieszczono złoty krzyż ozdobiony szlachetnymi kamieniami ${ }^{28}$. W skale Golgoty, według relacji Cyryla Jerozolimskiego, widoczne były pęknięcia powstałe w momencie śmierci Chrystusa ${ }^{29}$. W czasie naprawy zniszczeń dokonanych przez Persów w 6I4 roku skałę Golgoty przykryto specjalnym baldachimem, chroniącym ją przed niekorzystnymi warunkami atmosferycznymi. Według opisu zawartego w dziele Breviarius de Hierosolyma pochodzącym z VI wieku dziedziniec Golgoty był podzielony na mniejsze przestrzenie, do wydzielenia których służyły przenośnie bramki i ogrodzenia ${ }^{30}$.

Dziedziniec, na którym znajdowała się Golgota, posiadał jeszcze dwa ważne dla liturgii miejsca, które tworzyły przestrzeń liturgiczną dla wielu celebracji związanych z krzyżem Chrystusa. Pierwsze z nich to dość szeroka

\footnotetext{
26 IE 46, 5.

27 Por. E. Bermejo Cabrera, La proclamación de la Escritura ..., dz. cyt., s. 333.

28 Por. R. Salvarani, Il Santo Sepolcro..., dz. cyt., s. 53.

29, „[...] oskarży cię ta święta Golgota, która do dziś wskazuje, jak wtedy dla Chrystusa rozpadły się skały...” (Katecheza I3, 39, w: Cyryl Jerozolimski, Katechezy..., dz. cyt., s. 206).

30 Por. R. Salvarani, Il Santo Sepolcro..., dz. cyt., s. 83.
} 
i otwarta przestrzeń przed skałą Golgoty. Nosiło ono nazwę Ante Crucem. To tam przybywały liczne procesje, tam też wierni oczekiwali na otwarcie drzwi Martytrium lub Anastasis. Drugie zaś miejsce to wąska i dużo mniejsza kaplica znajdująca się za skałą Golgoty. Nosiła ono nazwę Post Crucem i posiadała dwie bramy, które umożliwiały płynne przejście uczestników liturgii sprawowanych w tym właśnie miejscu w odpowiednich dniach roku liturgicznego. Według relacji Egerii w kaplicy Post Crucem przechowywano ważne dla Jerozolimy relikwie. Poza relikwią Prawdziwego Krzyża znajdował się tam pierścień Salomona oraz ampułka z olejem, którym namaszczano królów izraelskich (por. IE 37,I-3) ${ }^{31}$. Relikwie te czczono w czasie celebracji. Szczególną rolę Post Crucem odgrywało w Wielkim Tygodniu. Według Egerii w Wielki Czwartek właśnie tam celebrowano mszę świętą upamiętniającą ustanowienie Eucharystii. Była to jedyna Eucharystia celebrowana w tym miejscu w ciągu roku (por. IE 35,2). Warto zauważyć, że kilkadziesiąt lat później Lekcjonarz ormiański przeniósł tę Eucharystię do znacznie większej przestrzeni, którą tworzyło Ante Crucem ${ }^{32}$. Umieszczając wielkoczwartkową Eucharystię w miejscu związanym z krzyżem, liturgia Jerozolimy podkreślała teologiczną łączność ofiary krzyżowej i ofiary eucharystycznej33. W Wielki Piątek na dziedzińcu, na którym znajdowała się Golgota, kończyła się procesja z bazyliki Eleona na Górze Oliwnej, po czym w kaplicy Post Crucem rozpoczynała się adoracja relikwii Krzyża Świętego:

Wtedy ustawia się tron biskupa na Golgocie, za Krzyżem, gdzie teraz stoi. Biskup zasiada na tronie i ustawia się przed nim stół nakryty lnianą tkaniną. Diakoni stają dookoła. Przynoszą srebrną, pozłacaną skrzynkę, w której jest święte drzewo Krzyża, otwierają skrzynkę, kładą na nim tak drzewo, jak i tabliczkę. Kiedy już położą je na stole, biskup, siedząc, bierze w ręce oba końce świętego drzewa, diakoni zaś, którzy stoją wokół, pilnują. Pilnuje się tak dlatego, że zgodnie ze zwyczajem każdy z całego ludu - wierny czy katechumen - podchodząc, nachyla się nad stołem, całuje drzewo święte i odchodzi. A ponieważ kiedyś - nie wiem kiedy - jak mówią - ktoś odgryzł

$3^{3 \mathrm{I}}$ Por. M. Augé, I santuari costantiniani di Palestina e il progressivo struttuarsi del ciclo annuale cristiano, „Rivista Liturgica” I00 (2013), s. 324.

32 Por. Le codex arménien Jérusalem I2I, dz. cyt., s. 269.

33 Por. C. García del Valle, Jerusalén ..., dz. cyt., s. I26-I27. 
i skradł kawałek ze świętego drzewa, teraz diakoni, którzy stoją wokół, pilnują, by któryś z podchodzących nie ośmielił się znowu tak uczynić34.

Jak było w przypadku wielkoczwartkowej Eucharystii, tak też adoracja krzyża $\mathrm{w}$ źródłach ormiańskich ma miejsce na dziedzińcu przed skałą Golgoty, a nie w kaplicy Post Crucem $^{35}$. Podobne przekazy zawierają także źródła gruzińskie ${ }^{36}$. Przytoczone wyżej różnice świadczą o ewolucji liturgii jerozolimskiej. Pomiędzy relacją Egerii a przekazami ormiańskimi i gruzińskimi zachodzą różnice ukazujące żywy i dynamiczny charakter liturgii jerozolimskiej, która rozwijała się, zmieniała i ewoluowała w zmieniających się warunkach, w jakich przychodziło żyć Kościołowi.

\subsection{Anastasis}

Trzecia przestrzeń liturgiczna kompleksu sakralnego wybudowana przez cesarza Konstantyna to ogromna kaplica o kształcie wielkiej absydy, wzniesiona po zachodniej stronie całego kompleksu i przylegająca do dziedzińca, na którym znajdowała się skała Golgoty. Kaplica ta we wszystkich źródłach zwana jest Anastasis. Egeria w następujących słowach określa to miejsce i wyjaśnia jego nazwę: „,sancta ecclesia qua est ad Anastase, id est in eo loco ubi Dominus resurrexit post passionem" ${ }^{37}$. Od strony dziedzińca otwierała się ona imponującą fasadą o szerokości 46 metrów, zawierającą aż ośmioro drzwi, przez które można było dostać się do jej wnętrza. Centrum Anastasis tworzyła wielka rotunda zwieńczona kopułą i podtrzymywana przez rząd kolumn i pilastrów, wzniesiona nad niewielką, ale bogato zdobioną konstrukcją, edykułem, kryjącym skałę, w której wykuto Grób Pański ${ }^{3}$. Przestrzeń do celebracji liturgii tworzyła zarówno cała kaplica Anastasis, jak i sam edykuł Bożego Grobu. Wejście do niego od strony wschodniej było wysuniętą sporo do przodu bramą z dwoma skrzydłami, najprawdopodobniej w formie kraty, a nie klasycznych drzwi i znajdowało się na osi wyznaczonej przez główną absydę Martyrium i centrum kaplicy Anastasis. Na jego określenie Egeria

\footnotetext{
34 IE 37, I-2.

35 Por. Le codex arménien Jérusalem I2I, dz. cyt., s. 28I.

36 Por. Le grand lectionnaire..., dz. cyt., s. 97.

37 IE 48, I.

${ }^{8}$ Por. R. Salvarani, Il Santo Sepolcro..., dz. cyt., s. 5I-53.
} 
używała terminu hostium. Wchodziły przez nie wszystkie osoby, które pełniły posługi liturgiczne w czasie celebracji wewnątrz Bożego Grobu. Po stronie północnej i południowej edykułu znajdowały się ponadto dwie niskie boczne kraty-bramy, być może otwierane i traktowane również jako wejścia do kaplicy Grobu Pańskiego. Egeria nazywa je cancelli lub cancelli interiores. Przestrzeń wyznaczona przez wejście oraz bramy-kraty, określana w Itinerarium terminami intra cancellos lub intra cancellos interiores była zwykle przeznaczona dla biskupa i odgrywała ważną rolę w liturgii jerozolimskiej od IV wieku ${ }^{39}$. W tym miejscu w oktawie Paschy biskup stawał wobec neofitów i głosił im katechezy wprowadzające w wiarę:

Gdy nadejdą dni Paschy, przez owe osiem dni, to jest od Paschy aż do oktawy [...] biskup staje wsparty o kratę, która jest wewnątrz groty Anastasis, i objaśnia wszystko, co dotyczy chrztu ${ }^{40}$.

Opisana w ten sposób postawa biskupa sugeruje, że owe cancelli interiores nie mogły być wyższe niż mniej więcej połowa wzrostu dorosłego człowieka, a więc przestrzeń liturgiczna przez nie wyznaczona była widoczna dla zebranych w Anastasis wiernych. W tym miejscu także - również pod przewodnictwem biskupa - dokonywało się codzienne Lucernarium otwierające modlitwę wieczorną Kościoła, o którym Egeria pisze, iż w Jerozolimie nosiło ono nazwę Licinicon (por. IE 24, 4):

O godzinie dziesiątej - która tu zwie się licinicon, u nas zaś lucernare - cały tłum znów zbiera się w Anastasis. Zapalone zostają wszystkie pochodnie oraz świece i robi się bardzo jasno. Światło to zaś nie bierze się z zewnątrz, lecz z wnętrza groty Grobu Pańskiego, to jest spoza kraty, gdzie dniem i nocą świeci się lampa ${ }^{41}$.

Codzienne nieszpory, oprócz zapalenia lamp obejmowały także śpiew psalmów, hymnów i antyfon, modlitwę litanijną oraz błogosławieństwo katechumenów i procesję na Golgotę. Egeria pisze wyraźnie, iż „takie nabożeństwo odbywa się codziennie przez sześć dni tygodnia u Krzyża i w Anastasis” (IE 24, 7).

\footnotetext{
39 Bardziej szczegółowo na temat wyglądu edykułu Bożego Grobu i przestrzeni liturgicznej, jaką tworzył por. T. Bać, Geneza i znaczenie ceremonii „Świętego Ognia” w Bazylice Bożego Grobu na podstawie źródeł liturgii jerozolimskiej do XIII wieku, „Resovia Sacra” 2I (20I4), s. $47-49$.

40 IE 47, I.

4I IE 24, 4.
} 
Modlitwa ta posiadała cechy oficjum katedralnego i miała ludowy charakter, o czym świadczy bardzo żywy udział wiernych, procesje oraz śpiew odpowiednio dobranych tekstów ${ }^{42}$. Naturalne stało się zatem, że także obrzędy Wigilii Paschalnej rozpoczynały się w Anastasis od zapalenia przez biskupa lampy i uroczystej procesji ze światłami do Martyrium ${ }^{43}$. W późniejszych wiekach ryt ten stał się początkiem obrzędu tzw. świętego ognia, czyli jednej z najbardziej charakterystycznych dla Jerozolimy celebracji paschalnych ${ }^{44}$.

W przestrzeni intra cancellos interiores miała miejsce także inna, charakterystyczna dla Anastasis, celebracja. Otóż każdej niedzieli o świcie biskup, w wypełnionej wiernymi i oświetlonej niezliczoną liczbą lamp Anastasis, z tego właśnie miejsca proklamował Ewangelię o zmartwychwstaniu Chrystusa (por. IE 24, 9) ${ }^{45}$. W zgromadzeniu rozchodził się wówczas piękny zapach kadzidła:

Biskup wchodzi za kratę, bierze Ewangeliarz, podchodzi do wejścia i sam czyta o Zmartwychwstaniu Pańskim ${ }^{46}$.

Można zatem powiedzieć, że każdej niedzieli wczesnym rankiem wspólnota chrześcijańska Jerozolimy pod przewodnictwem biskupa, poprzez uroczystą proklamację Ewangelii o zmartwychwstaniu przeżywała i doświadczała paschalnej mocy żyjącego Zbawiciela. Przestrzeń zaś pomiędzy bramami edykułu Grobu Pańskiego, w której stawał biskup z ewangeliarzem w rękach, była rzeczywiście ogrodem, w którym paschalny Chrystus spotkał Marię Magdalenę i przekazał jej prawdę o zmartwychwstaniu ${ }^{47}$. Dzięki przekonaniu Kościoła jerozolimskiego o tym, iż miejsce zmartwychwstania Chrystusa jest najbardziej odpowiednie do głoszenia prawdy o Jego zwycięstwie nad śmiercią, w bazylice Martyrium ani w żadnym innym miejscu całego kom-

42 Por. P. Regan, Paschal Lucernarium. Structure and Symbolism, „Worship” 82 (2008), s. 100.

43 Obrzęd ten jest świadectwem ewolucji liturgii jerozolimskiej pomiędzy wiekami V a X, co dokumentują świadectwa źródeł ormiańskich, gruzińskich i Typikon Kościoła Anastasis. Por. T. Bać, Światło Paschy w liturgii jerozolimskiej pierwszych wieków, „Verbum Vitae” 2016 nr 29, s. 330-333.

44 Por. T. Bać, Geneza i znaczenie..., dz. cyt., s. 34-57.

45 Tradycję tę potwierdza także Lekcjonarz ormiański, łącząc proklamację Ewangelii o zmartwychwstaniu z Ewangelią o pogrzebie Chrystusa. Por. M. Augé, I santuari costantiniani..., dz. cyt., s. 329.

46 IE 24, IO.

47 Por. E. Bermejo Cabrera, La proclamación de la Escritura..., dz. cyt., s. 345. 
pleksu budowli konstantyńskich nie było ambony, rozumianej jako specjalny pulpit. Według Egerii w proklamacji słowa Bożego miały znaczenie przestrzeń, w której się to działo, oraz minister - biskup lub prezbiter ${ }^{48}$. Mogło się to dziać w Martyrium lub w Anastasis, gdzie Ewangelia o zmartwychwstaniu wybrzmiewała w sposób szczególnie silny i oddziałujący na emocje wiernych (por. IE 24, IO). W Itinerarium nie ma zaś żadnej wzmianki o ambonie jako stałej strukturze i elemencie wyposażenia kościoła. W Anastasis Kościół jerozolimski celebrował także w niektóre dni Eucharystię, ale było to zawsze złączone z celebracjami odbywającymi się w Martyrium.

W kontekście rozważań o przestrzeni liturgicznej i jej wyposażeniu warto zwrócić uwagę, że jeszcze w pierwszym tysiącleciu architektoniczny kształt Anastasis zarówno na Wschodzie, jak i na Zachodzie stał się modelem dla chrzcielnic, gdyż chrzest od strony teologicznej jest zanurzeniem się w śmierci i zmartwychwstaniu Chrystusa ${ }^{49}$.

\section{WNIOSKI KOŃCOWE}

Architekci Konstantyna w pierwszej połowie IV wieku wznieśli w Jerozolimie bardzo dobrze przemyślane budowle, które z jednej strony obejmowały miejsca najświętsze dla chrześcijan, czyli skałę Golgoty i Grób Pański, a z drugiej były bardzo funkcjonalne od strony liturgicznej i celebracyjnej. Mogły pomieścić miejscową wspólnotę Kościoła oraz rzesze pielgrzymów i umożliwiły rozwój typowych dla Jerozolimy form liturgicznych, które później wywarły ogromny wpływ na celebracje w całym świecie chrześcijańskim. Co więcej, architektura konstantyńskich budowli na Golgocie umożliwiała istnienie, rozwój i przenikanie się dwu form chrześcijańskiej liturgii, katedralnej i monastycznej, które przez wieki w naturalny sposób ze sobą współistniały.

Zespół budowli sakralnych wzniesionych w miejscu śmierci i zmartwychwstania Chrystusa charakteryzuje się jednością i spójnością. Bazylika Martyrium jest złączona ze skałą Golgoty, przed i za którą wierni mogli się modlić na wolnym powietrzu. Miejsce krzyża natomiast prowadzi w logiczny sposób

\footnotetext{
48 Por. E. Bermejo Cabrera, La proclamación de la Escritura ..., dz. cyt., s. 499-500.

49 Por. C. Militello, La casa del popolo di Dio. Modelli ecclesiologici, modelli architectonici, Bologna 2006, s. 4I.
} 
ku Anastasis, czyli ku tajemnicy zmartwychwstania. Źródła liturgiczne pierwszego tysiąclecia są świadectwem takiego właśnie spójnego i całościowego rozumienia przestrzeni, w jakiej sprawowana była liturgia, co widać w licznych procesjach i przejściach pomiędzy poszczególnymi częściami całego kompleksu oraz w rytuale otwierania i zamykania drzwi, bram i krat, które tę przestrzeń dzieliły. Jednocześnie jednak należy pamiętać, że każde z tych miejsc tworzyło także oddzielną przestrzeń liturgiczną, w której wspólnota uczestniczyła w sprawowanej liturgii. Ołtarz i katedra biskupa znajdowały się w absydzie Anastasis i wokół nich koncentrowało się życie eucharystyczne Kościoła jerozolimskiego. Jednak, w określonych momentach roku liturgicznego lub przy specjalnych okazjach katedrę biskupa przenoszono albo na środek bazyliki albo na miejsce Ante lub Post Crucem, które wówczas stawały się centrum i ośrodkiem całej celebracji. Gdy zaś biskup stawał intra cancellos, to w Anastasis koncentrowało się życie liturgiczne wspólnoty. Owa jedność przestrzeni liturgicznej wyrażająca się w wielości miejsc, w których odbywają się celebracje, jest bardzo charakterystyczna dla liturgii jerozolimskiej i nawet po zburzeniu budowli konstantyńskich, w bazylice Bożego Grobu zaprojektowanej i wzniesionej przez krzyżowców uderza ona z całą siłą.

Budynki sakralne wzniesione przez cesarza Konstantyna na Golgocie służyły zarówno wspólnocie chrześcijan Jerozolimy, jak i przybywającym do niej pielgrzymom z całego chrześcijańskiego świata. Były więc bardzo funkcjonalne. Można powiedzieć, że ich przestrzeń liturgiczna służyła Kościołowi rozumianemu jako wspólnota. Już od obrzędów katechumenatu kandydaci do chrztu byli wprowadzani w przestrzeń liturgiczną. W centrum bazyliki Martyrium słuchali katechez, odbywali skrutynia, byli egzorcyzmowani i błogosławieni. Oddanie Symbolu odbywało się w absydzie, chrzest i bierzmowanie w baptysterium na zewnątrz, pierwsza Eucharystia w Martyrium, a katechezy mistagogiczne w Anastasis, przed kaplicą Bożego Grobu. Biskup swoją rolę pasterza wspólnoty ukazywał wówczas, gdy zasiadał na katedrze, która była przenośna i, według świadectwa Egerii, w zależności od potrzeb stawiana w różnych miejscach (np. w centrum bazyliki Martyrium lub Post Crucem). W ten sposób rola pasterza uzewnętrzniała się wobec całej wspólnoty, która w różnym czasie gromadziła się w różnych miejscach. Brak ambony w tradycyjnym rozumieniu konstrukcji służącej do proklamacji słowa Bożego na podwyższeniu ukazuje, że sama przestrzeń oraz głoszący słowo biskup lub prezbiter są nośnikami Bożego słowa w zgromadzeniu, a jedynym znakiem ukazującym moc tego słowa jest pusty grób Chrystusa. W omawianej przestrzeni liturgicznej własne miejsce mieli duchowni, mnisi 
i mniszki, mieszkańcy Jerozolimy i rzesze pielgrzymów. To oni tworzyli Kościół, wypełniając przestrzeń podczas liturgii.

Układ przestrzenny całego kompleksu Martyrium - Crux-Anastasis miał fundamentalne znaczenie dla powstania i początkowej ewolucji liturgii jerozolimskiej, a także dla jej charakteru, struktury i właściwych dla niej rytów. Poszczególne celebracje roku liturgicznego oraz cykl lekcjonarza formowały się właśnie na podstawie miejsc, w których były sprawowane. Nic zatem dziwnego, że obrzędy celebrowane w Bożym Grobie były chętnie naśladowane i przenoszone przez pielgrzymów na cały ówczesny chrześcijański świat. Szczególną wartość miały zawsze celebracje paschalne, w których wiele dzisiejszych elementów, takich jak procesje, rola światła czy adoracja krzyża mają swoje korzenie w jerozolimskich celebracjach w Anastasis, na Golgocie czy w Martyrium. I chociaż dzisiaj w rytach paschalnych nie widać już tego przestrzennego powiązania ze Świętym Miastem, to jednak bez Jerozolimy i świątyń zbudowanych tam przez Konstantyna dzisiejsza liturgia - także ta rzymska - wyglądałaby zupełnie inaczej.

\section{BibLiOgRAFiA}

\section{Źródła liturgii jerozolimskiej}

Le codex arménien Jérusalem I2I, t. 2: Édition comparée du texte et de deux autres manuscrits. Introduction, textes, traduction et notes par A. Renoux, Turnhout I97I.

Cyryl Jerozolimski, Katechezy przedchrzcielne i mistagogiczne, red. W. Kania, J. Bojarski, M. Bogucki, Kraków 2000.

Egeria, Pielgrzymka do miejsc świętych, w: Do Ziemi Świętej. Najstarsze opisy pielgrzymek do Ziemi Świętej IV-VIII w., red. P. Iwaszkiewicz, Kraków 20IO, s. II8-I99.

Euzebiusz z Cezarei, Życie Konstantyna, red. T. Wnętrzak, Kraków 2007.

Le grand lectionnaire de l'Église de Jérusalem $\left(V^{e}-V I I I^{e}\right)$, t. I-2, éd. M. Tarchnischvili, Louvain I959-I960.

Hieronim ze Strydonu, List 58 do [prezbitera] Paulina, w: Hieronim ze Strydonu, Listy II (5I-79), red. M. Ożóg, H. Pietras, Kraków 20I0, s. 69(69*)$-76\left(76^{*}\right)$. 
Itinerarium Egeriae, a cura di A. Franceschini, R. Weber, w: Itineraria et alia geographica, Turnhout I958, s. 29-I03 (Corpus Christianorum. Series Latina, I75).

Thibaut J.-B., Ordre des Offices de la Semaine Sainte à Jérusalem du IV au $X^{e}$ siècle. Études de liturgie et de la topographie palestiniennes, Paris I926.

\section{Opracowania}

Augé M., I santuari costantiniani di Palestina e il progressivo struttuarsi del ciclo annuale cristiano, „Rivista Liturgica” I00 (2013), s. 322-343.

Bać T., Geneza i znaczenie ceremonii „Świętego Ognia” w Bazylice Bożego Grobu na podstawie źródet liturgii jerozolimskiej do XIII wieku, „Resovia Sacra" 2I (20I4), s. 33-57.

Baldovin J. F., The Urban Character of Christian Worship. The Origins, Development, and Meaning of Stational Liturgy, Roma 1987.

Bermejo Cabrera E., La proclamación de la Escritura en la liturgia de Jerusalén. Estudio terminologico del "Itinerarium Egeriae", Jerusalem 1993.

Canard M., La destruction de l'eglise de la Resurrection par le calife Hakim et l'histoire de la descente du feu sacré, „Byzantion” 35 (I965), s. I6-43.

Galadza D., La tradizione liturgica di Gerusalemme e la distruzione dei luoghi santi, „Rivista Liturgica” I00 (2013), s. 396-406.

García del Valle C., Jerusalén, la liturgia de la Iglesia madre, Barcelona $200 \mathrm{I}$.

Janeras S., La Settimana Santa nell'antica liturgia di Gerusalemme, w: Hebdomadae sanctae celebratio. Conspectus historicus comparativus, cura et studio A. G. Kollamparampil, Roma 1997, s. 19-50.

Janeras S., Le Vendredi-Saint dans la tradition liturgique byzantine. Structure et histoire de ses offices, Roma 1988.

Klimas S. N., Autentyczność Bożego Grobu w Jerozolimie. Badania historiograficzne, archeologiczno-architektoniczne $i$ udokumentowane $w$ zabytkach (I-Xw.), Kalwaria Zebrzydowska 2017.

Marchadour A., Neuhaus D., La terra, la Bibbia e la storia. „Verso il paese che io ti indicherò", Milano 2007.

Militello C., La casa del popolo di Dio. Modelli ecclesiologici, modelli architectonici, Bologna 2006.

Regan P., Paschal Lucernarium: Structure and Symbolism, „Worship” 82 (2008), s. 98-II8.

Salvarani R., Costantino e la nascita dei santuari Cristiani dei luoghi santi, „Rivista Liturgica” IOO (20I3), S. 30I-32I. 
Salvarani R., Il Santo Sepolcro di Gerusalemme. Riti, test, e racconti tra Costantino e l'età delle crociate, Città del Vaticano $20 \mathrm{I} 2$. Seweryniak H., Geografia wiary, Warszawa 20 Io.

\section{SUMMARY}

\section{The liturgical space in the Constantine's basilica of the holy sepulchre in Jerusalem}

The article examines the question of the liturgical space in the complex of sacred buildings, commemorating the place of the death and resurrection of Jesus Christ, risen by the Emperor Constantine the Great at the beginning of the IV century in Jerusalem. The complex was comprised of three single sites. The first of them was the great basilica called Martyrium where most of the liturgies were celebrated. The second place embraced the spacious courtyard with the rock of Golgotha at the top of which was the golden and precious cross. The sources usually call it Crux or Golgotha. The third liturgical space consisted of the impressive rotunda of Anastasis containing the aedicule of the Tomb of Jesus. This way of creating the liturgical space permitted the liturgy of Jerusalem in the first millennium to develop its proper celebrations which further became the model for other rites and liturgies of the East and West. The whole complex was destroyed in 1009 and the Martyrium together with the courtyard of the Golgotha were never rebuilt. 